\title{
Entre la Pragmática y la Lexicografía: la marca humorístico en los diccionarios monolingües de aprendizaje del español
}

ISABEL SANTAMARÍA PÉREZ

Universidad de Alicante

Lo que por sí es gracioso, sean las que fueren las palabras con que se dice es facecia de cosa: lo que mudando las palabras pierde la sal tiene toda su gracia en las palabras mismas (Ciceron, De Oratore, II, LXII, 252)

\section{INTRODUCCIÓN}

El humor es uno de los fenómenos que más interés ha suscitado desde la antigüedad y su estudio ha sido abordado desde diversos puntos de vista, entre ellos el lingüístico. Desde un enfoque pragmático se define el humor verbal como un mecanismo de transgresión o ruptura de los principios o procedimientos cognitivos que guían la interpretación de los enunciados, y se ha elaborado modelos de análisis para explicar qué mecanismos utilizamos para construir y comprender enunciados de carácter humorístico (Raskin, 1985; Torres Sánchez, 1999; Attardo, 2001; Hidalgo Downing e Iglesias Recuero, 2009); esto es, se ha intentado explicar cómo los hablantes codificamos nuestra intención, en este caso humorística, en el lenguaje, tarea bastante compleja porque cualquier palabra puede tener una intención de esta índole dependiendo de la situación comunicativa. Por su parte, la lexicografía, ante el estímulo de las corrientes pragmáticas, también se ha preocupado por incluir no sólo los significados nucleares o denotativos sino también los sentidos o las intenciones del hablante a partir de las llamadas marcas de valoración o de actitud y más recientemente pragmáticas, entre las que se incluyen despectivo, peyorativo, insulto, irónico, humorístico, etc., elementos ampliamente estudiados por autores como Garriga (1996 y 1998), Pérez Lagos (1999), Jiménez Hurtado (2001), Marimón (2005), Azorín y Santamaría (2010), entre otros.

En ese espacio común es en el que este trabajo cobra sentido. El grupo GRIALE al que pertenezco tiene como objeto central encontrar un tratamiento lingüístico satisfac- 
torio para el análisis del humor verbal en español, ${ }^{1}$ de manera que se pueda aplicar a la enseñanza de español para estudiantes extranjeros.

A la vista de este objetivo último - comprender los mecanismos del humor y aplicarlo a la enseñanza de extranjeros - parece importante, además de tener un marco teórico consolidado ${ }^{2}$ (Ruiz Gurillo y Padilla, 2009), tener una idea clara acerca de cómo el humor es tratado como fenómeno verbal-comunicativo en nuestro idioma. Recurrir a los diccionarios de aprendizaje es un punto de partida, puesto que es allí donde el estudiante extranjero con un nivel alto de español ${ }^{3}$ espera encontrar una primera respuesta para comprender enunciados irónicos-humorísticos, pero también para poder crear sus propios mensajes humorísticos.

Con este objetivo de fondo, el propósito fundamental de este trabajo es mostrar cómo aparece codificado en los diccionarios de aprendizaje del español el sentido humorístico, ver en qué medida las etiquetas empleadas son clarificadoras y favorecen el desarrollo pragmático de los alumnos extranjeros y por último, analizar el tipo de unidades léxicas que llevan la marca humorístico en los diccionarios seleccionados. Para ello, partiré del estudio de concepto de 'humorístico' en los diccionarios a partir de la información contenida en los preliminares de los diccionarios, pues dicen mucho sobre las dificultades que entrañan tanto la delimitación y codificación de este concepto, como el establecimiento de unos criterios estables para la aplicación de la marca 'humorístico' a lo largo de la microestructura del diccionario.

Para llevar a cabo este estudio centraremos el trabajo en el análisis de los siguientes diccionarios monolingües de aprendizaje (Azorín, 2010; Azorín y Martínez Egido, 2010):

Diccionario para la enseñanza de la lengua española. Español para extranje$\operatorname{ros}[$ Alcalá $]$

\section{Diccionario Salamanca de la lengua española [Salamanca]}

Diccionario para estudiantes de español [Espasa]

\footnotetext{
${ }^{1}$ Esta trabajo se enmarca dentro de los estudios llevados a cabo por el Grupo GRIALE que actualmente cuenta con el Proyecto de Investigación «Aplicaciones a la clase de español como lengua extranjera de la ironía y el humor» (FFI 2008-00178), dirigido por la doctora Leonor Ruiz Gurillo.

${ }^{2}$ Para el análisis de los enunciados humorísticos partimos de los presupuestos teóricos de GRIALE, donde en un primer momento, estudiamos la ironía como fenómeno pragmático, y propusimos un análisis de la conversación a partir de las teorías posgriceanas, en las que la ironía surge por la violación de los principios conversacionales. Estos presupuestos teóricos de GRIALE son el punto de partida para estudiar el humor como hecho pragmático que se activa con el Principio de Inversión, es decir, las implicaturas conversacionales particularizadas que genera el enunciado se invierten y en consecuencia, los principios conversacionales. Así, la interpretación irónico-humorística que puede tener un enunciado se apoya en indicadores (en sí humorísticos, como la fraseología) y marcas (ayudan a valorar el humor, como el tono o los acotadores) que suscitan inferencias generalizadas en el oyente.

${ }^{3}$ Según las exigencias del Programa MARCO de la Unión Europea, la ironía y el humor verbal se deben enseñar en los niveles competenciales C1 y C2 (usuarios competentes) y B2 (usuario independiente).
} 


\section{Diccionario de español para extranjeros [SM]}

Utilizaremos como referencia la versión electrónica del Diccionario de uso (DUE) de María Moliner (2008) porque, como su propia autora indica en el primer párrafo de la Presentación a la primera edición, el propósito de la obra era ayudar en el uso del español tanto a estudiantes nativos como extranjeros:

La denominación de uso aplicada a este diccionario significa que constituye un instrumento para guiar en el uso del español a los que lo tienen como idioma propio como a aquellos que lo aprenden ${ }^{4}$ y han llegado en el conocimiento de él a ese punto en el que el diccionario bilingüe puede y debe ser sustituido por un diccionario en el propio idioma que se aprende.

De igual modo he contrastado los resultados con el DRAE-2001, también en su edición electrónica que permite la búsqueda de determinadas categorías, por ser el diccionario académico el referente tradicional de la lexicografía española.

Desde el punto de vista metodológico he partido del DUE. Mediante las opciones de búsqueda avanzada que ofrece el diccionario, he seleccionado todas aquellas voces marcadas como 'humorístico' en el repertorio y he obtenido 182 entradas con esta característica. Tomando estas como punto de partida para crear un corpus léxico humorístico, he realizado la misma búsqueda en el resto de los diccionarios seleccionados con el fin de observar cómo se han codificado las voces que expresan esta intención comunicativa precisa.

2. EL COMPONENTE PRAGMÁTICO EN LOS DICCIONARIOS DEL ESPAÑOL: LA INTENCIÓN HUMORÍSTICA

De todos es sabido que en el último tercio del siglo XX se produce un importante cambio en el estudio de las ciencias del lenguaje: se pasa del estudio de la lengua como sistema a la lengua como comunicación, y surgen nuevas disciplinas como la pragmática, el análisis del discurso, la sociolingüística, etc. que renuevan los objetivos y la metodología de la enseñanza de lenguas no maternas (Gutiérrez, 2004: 533). Ante esta nueva concepción, ya no es suficiente con crear enunciados gramaticales correctos $y$, en consecuencia, el proceso de aprendizaje de una lengua no puede quedar limitado al estudio de las reglas fonológicas, morfológicas, sintácticas o la adquisición del léxico de un sistema lingüístico, sino que es una tarea mucho más compleja que implica que los aprendientes de esa lengua adquieran suficientes recursos para ser capaces de crear enunciados coherentes y adecuados a cada contexto situacional y de igual modo adquieran suficientes destrezas comunicativas para ser capaces de resolver distintas situaciones y necesidades comunicativas, lo que se denomina desde hace tiempo competencia pragmática (Gutiérrez 2004: 536).

${ }^{4}$ El subrayado es nuestro. 
Estas nuevas exigencias en la enseñanza de una lengua no materna han llevado a que otras disciplinas, entre ellas la lexicografía, se vean obligadas a replantearse cómo introducir esta información de manera sistemática en sus obras, pues en los diccionarios no basta con incluir los significados literales o notas gramaticales, sino que también deben mostrar información sobre el uso (Azorín y Santamaría, 2010). Esta necesidad ha motivado que en los últimos años en la mayoría de los diccionarios, se incluyan notas informativas, abreviaturas, etc., sobre las particularidades de uso de una entrada. Pero no es menos cierto que, desde los orígenes de la Lexicografía hispánica, ${ }^{5}$ es habitual encontrar en la microestructura de los diccionarios, además de marcas diacrónicas, diatópicas, diatécnicas o gramaticales, otro tipo de marcación diasistemática que hace referencia al nivel social (culto, popular), al estilo (literario o poético) o a la intención con que se usa un determinado término (despectivo, irónico, etc.), marcación que poco a poco ha ido sistematizándose gracias a las investigaciones lingüísticas (Marimón, 2005: 34).

Como señala esta autora en el trabajo ya citado (2005: 34), bajo el epígrafe «intención del hablante» se encuentran en los diccionarios un conjunto heterogéneo de marcas diasistemáticas — marcas de valoración o actitud y más recientemente, pragmáticas - cuya conformación a lo largo de la historia de las obras lexicográficas ha sido más variable en sus contenidos y criterios que cualquier otro tipo de marcación. No es casual que esto sea así, ya que es la parte menos sistematizable del significado, la más difícil de codificar y fijar en un diccionario en la medida en que está condicionada por la intención de un hablante en una determinada situación de uso. La marca humorístico y todas las demás relacionadas con las intenciones de los hablantes (afectivo, despectivo, enfático, irónico o peyorativo, etc.) son muestra del interés de la Lexicografía por recoger en los diccionarios los significados que tienen que ver con los hablantes y con los distintos usos que estos hacen de la lengua.

Estas marcas de uso a las que nos referimos, que muestran las condiciones de empleo de voces y acepciones, constituyen un apartado clave en el diseño de la microestructura de todo diccionario, particularmente si se trata de un repertorio didáctico, y especialmente aquellos dedicados a aprendientes extranjeros, que precisan de mayor información sobre las posibilidades de uso de una palabra. La utilidad de estas etiquetas es, por tanto, incuestionable para identificar el significado de un ítem léxico en el

\footnotetext{
${ }^{5}$ Remitiendo a un trabajo de Azorín, la autora señalaba que la utilidad de las marcas de uso no ha escapado a los compiladores de diccionarios: «Desde los orígenes de la lexicografía española, aunque con una técnica lexicográfica todavía muy rudimentaria, autores como Covarrubias (1611) o Ayala Manrique (1693) vieran la necesidad de introducir en sus diccionarios información sobre las particularidades de empleo que presentaban algunas de las palabras recogidas en sus repertorios y que las apartaban del uso general. Pero no es hasta la publicación del Diccionario de Autoridades (1726-1739) cuando tome oficialmente carta de naturaleza este tipo de información al incluir la Academia la "calidad de las voces" como una pieza más de la microestructura del diccionario. A lo largo de sus 22 ediciones, el DRAE ha mantenido - con los ajustes pertinentes - el sistema de marcación heredado de Autoridades y, siguiendo su ejemplo, la mayoría de los diccionarios del español han venido empleando sin apenas cuestionar su pertinencia las marcas lexicográficas consolidadas por la tradición académica» (Azorín, 2010: 249).
} 
proceso de decodificación; pero es, sobre todo, en el proceso de codificación lingüística cuando las marcas adquieren un especial protagonismo ya que orientan al consultante sobre las restricciones de uso de las piezas léxicas (Azorín y Santamaría, 2010: 203221); esto es, si una voz se usa en situaciones formales o coloquiales, en contextos científicos y técnicos o con una intención despectiva o irónica.

Si se atiende a las concepciones tradicionales de pragmática y lexicografía, puede resultar paradójico hablar de pragmática en los diccionarios. El diccionario recoge el sistema, mientras que la pragmática estudia el lenguaje en uso. Por tanto, el diccionario es incapaz de sistematizar muchos de los contenidos no codificados de las unidades léxicas, aquellos que son objeto de estudio de la pragmática. Además, con los estudios pragmáticos, se ha visto que «el significado de nuestros mensajes depende mucho más de la interpretación de los oyentes de lo que se pensaba, lo que, en términos más accesibles, equivale a quitarle importancia al diccionario y dársela a la situación comunicativa» (Pons, 2005: 37).

Cuando alguien emite un enunciado, debajo del significado literal, subyace el sentido, aquello que está implícito. Para que un acto comunicativo sea satisfactorio es necesario que el receptor capte la totalidad del mensaje, esto es, el destinatario de dicho enunciado debe ser capaz de comprender tanto el significado como el sentido, la información implícita, indispensable cuando aprendemos una segunda lengua (Gutiérrez, 2004: 542); en consecuencia, es necesario enseñar a los estudiantes no nativos que hay enunciados que van más allá de su significado denotado o literal y aportan contenidos implícitos, tales como el humor o la ironía, entre otros, lo que explicaría el intento más o menos afortunado por parte de los diccionarios de recoger los aspectos pragmáticos en la descripción de sus voces y acepciones.

Por tanto, es cierto que Lexicografía y Pragmática son dos disciplinas con distintos objetivos y métodos, pero ambas convergen en el estudio del significado de las palabras y expresiones de una lengua que hacen posible la comunicación entre sus usuarios y, en consecuencia, su relación es, como indica Pérez Lagos (1999: 121), cada vez más ineludible:

Parece imprescindible, pues, para una Lexicografía acorde con los últimos tiempos, profundizar en el aspecto pragmático y funcional, y que el diccionario ofrezca el uso del lenguaje no como un mero conjunto de observaciones complementarias de su tradicional papel definitorio, sino como la otra cara inseparable de nuestro léxico sin la cual es imposible llegar a un completo conocimiento de nuestra lengua actual.

Uno de estos contenidos pragmáticos es precisamente el significado humorístico que aquí se plantea. Desde las teorías pragmáticas más actuales que conciben el humor como un fenómeno semántico-pragmático, ${ }^{6}$ nuestro grupo de investigación adopta el

${ }^{6}$ Son diversos los enfoques y múltiples las orientaciones a la hora de abordar el estudio del humor lo que ha generado diferentes formas de entenderlo y conceptualizarlo y desde diferentes puntos de 
modelo inferencial para la interpretación de los enunciados humorísticos, que defienden que los efectos humorísticos surgen como consecuencia de la violación de las máximas conversacionales y se basan en que el humor es el resultado de la percepción de algo que resulta incongruente. Esto supone que en el humor se activan diversos marcos o espacios mentales sobre los que se construye una incongruencia que en unos casos se resuelve por la negación de uno de los marcos y en otros permite la convivencia de ambos (Ruiz Gurillo, 2006: 117); esto es, el enunciado que se presenta es compatible con dos esquemas o interpretaciones diferentes, de manera que aquello que se esperaba no ocurre, sucede algo fuera de lo normal que es lo que produce humor. Pero para que esta comunicación sea efectiva, el emisor debe proporcionar ciertos indicios de sus intenciones para que el oyente pueda inferir estas intenciones con la ayuda de tales indicios y del contexto comunicativo, de tal modo que hablante y oyente deben participar activamente en el intercambio comunicativo. Desde un punto de vista lingüístico, el humor sólo tiene explicación si se concibe la comunicación en sentido amplio; es decir, si se asume que comunicarse no consiste únicamente en la codificación de un significado por parte de un hablante y en su respectiva decodificación por parte de un destinatario. La comunicación se basa en la transmisión de intenciones, y tiene éxito cuando dichas intenciones son interpretadas correctamente por los destinatarios (GRIALE, 2011: 9).

Resulta, por tanto, bastante complejo intentar sistematizar aquellos enunciados humorísticos que son actos de habla en los que el emisor manifiesta su estado de ánimo respecto a algo o expresa ciertos sentimientos. En los intercambios humorísticos los elementos lingüísticos no poseen un significado lúdico o humorístico en sí mismos, sino que es su uso en la comunicación lo que les confiere este sentido, como resultado de la actitud lúdica del emisor, y de la interacción entre la información lingüística explícita, la información implícita y los elementos contextuales en el proceso interpretativo (Torres Sánchez, 1999: 99). En este caso, el aspecto humorístico del lenguaje trasciende el nivel de las palabras y abarca todo el conjunto de la comunicación, lo que dificulta, limita y condiciona la aplicación de la marca 'humorístico' en los diccionarios. Es difícil etiquetar una palabra como humorística, puesto que cualquier palabra puede tener esta intención, de manera que sólo llevarán esta etiqueta aquellas que «ten-

vista: filosófico, semiótico, psicológico, social, etc. Dentro de las corrientes que se han ocupado del humor (Attardo, 1994) destaca tres tendencias: 1) Teorías de la superioridad, para las que toda experiencia humorística surge como manifestación del sentimiento de superioridad del hombre hacia el hombre. 2) Teorías de la descarga, para las que el humor es efecto de una descarga de energía física acumulada. 3) Teorías de la incongruencia, que consideran que el humor se basa en el descubrimiento de una realidad o un pensamiento que resulta incongruente con lo que se esperaba (cf. Torres Sánchez, 1997-1998). Torres Sánchez lleva a cabo un trabajo en español sobre el humor verbal que recoge las aportaciones de las teorías que desde un punto de vista pragmático se han acercado al estudio del humor: por un lado, aquellas adscritas al modelo del código, que restringen el estudio del humor verbal a la caracterización de las propiedades estructurales de los textos humorísticos; por otro, aquellas que adoptan un modelo inferencial para la interpretación de los enunciados humorísticos, las cuales defienden que los efectos humorísticos surgen como consecuencia de la violación de las máximas conversacionales y se basan mayoritariamente en la opinión de que el humor es resultado de la percepción de las incongruencias (Torres Sánchez, 1999: 105). 
gan un valor pragmático refrendado y aceptado por la comunicad que se trate» (Jiménez Hurtado, 2001: 388-389); esto es, deberemos limitar la marca humorístico a aquellas unidades que en todos los contextos tengan este sentido y en consecuencia, estos significados pragmáticos se hayan convencionalizado. Es evidente que el significado de un término solo encuentra su verdadero sentido cuando está en uso, pero no es menos cierto que los hablantes asignamos significados más o menos fijos a las palabras y expresiones de una lengua. En ocasiones, no es necesario acudir al contexto para detectar el humor, pues la expresión puede haber incorporado al código lingüístico el significado humorístico. Esto es habitual en las unidades fraseológicas; es decir, en expresiones que se han codificado como transmisoras de un valor humorístico o irónico. Así, si alguien califica algo como todo un poema está expresando que algo resulta tan excesivo, inapropiado y fuera de lo común que raya lo ridículo y provoca la risa (humor) y esto será así en todos los contextos, cada vez que se utilice esta expresión. Igualmente, si alguien pide la dolorosa se está aludiendo en sentido humorístico a la cuenta que hay que pagar. Por eso, queremos analizar las formas léxicas registradas en los diccionarios españoles que producen este efecto.

\section{EL SENTIDO HUMORÍSTICO EN LOS DMA}

El sentido humorístico, al igual que otros significados intencionales, son difíciles de codificar en los diccionarios debido a su dependencia del uso en contexto. Sin embargo, los intercambios humorísticos son una constante en nuestra cotidianeidad lingüística y por tanto, es un fenómeno verbal que debemos enseñar a los hablantes no nativos. Aunque el humor se considera un universal humano - ya lo decía Aristóteles, el hombre es el único animal que ríe - también sirve para poner de manifiesto el carácter o la visión del mundo de un grupo o comunidad hablante, que no siempre los estudiantes extranjeros comparten; por tanto, el humor también está marcado culturalmente (Iglesias Casal, 2000). Al igual que pudimos comprobar con el fenómeno de la ironía estamos ante un hecho lingüístico de carácter pragmático, pero claramente relacionado con lo cultural, de ahí que no sea fácil transferir o traducir un enunciado humorístico de una lengua a otra, y en consecuencia, tampoco es fácil enseñarlo a un aprendiente extranjero (Roca, 2009: 461).

En un diccionario didáctico para no nativos encontramos la marca de valoración 'humorístico' que nos advierte de las posibles connotaciones que afectan a una determinada unidad léxica, más allá de su significado denotativo. De manera que si una voz se etiqueta como 'humorístico', el autor del diccionario está diciendo al usuario de dicha obra que ese sentido, ese significado, esa valoración es de dominio común entre los hablantes nativos de una misma lengua.

Pongamos un ejemplo. Si un aprendiente de español se encuentra con el siguiente enunciado en que aparece la palabra fideo:

-Bueno, pues mi caso personal, como os explicaba, es un ejemplo que puede avalar mi teoría. 
-Sí, lo de que hay que ponerse al revés.

- Pero Aída, mujer, no interrumpas. Que a ti te interesa más a que a nadie, porque mira lo bien que te vendría mirarte al espejo y verte al revés, o sea, en lugar de verte gorda, verte delgada, hecha un fideo, que es como verdaderamente estás.

- ¡Ah! Pero ¿en eso consiste tu teoría, Jorge?

-En cierto modo sí.

[Beccaria, Lola (2001), La luna en Jorge, Barcelona, Destino, Corpus CREA, $04 / 03 / 2011]$

Ante sus dudas el estudiante extranjero acude a un diccionario monolingüe en español, y se encuentra con la siguiente entrada, donde la definición lexicográfica va precedida de una serie de marcas informativas que intentan suplir lo que presumiblemente este desconoce, por lo que lo más probable es que el proceso de decodificación se lleve a cabo con éxito, pues el consultante dispone de una serie de pistas para llegar al conocimiento de un ítem léxico determinado.

fideo 2 COLOQUIAL; INTENSIFICADOR, HUMORÍSTICO. Persona muy delgada: María es un fideo, no come nada. Desde que haces esta dieta estás hecho un fideo. [SALAMANCA]

Cuando el estudiante lea la información contenida bajo el lema fideo, comprenderá que la segunda acepción se utiliza en situaciones comunicativas coloquiales y puede usarse para intensificar una cualidad de esa persona o bien para provocar una sonrisa o la risa en el receptor.

Debido precisamente a que el sentido humorístico de una pieza léxica se adquiere en una situación comunicativa concreta, es difícil que una expresión pueda considerarse humorística si no está contextualmente definida. Este hecho ocasiona graves problemas desde el punto de vista lexicográfico, y sin embargo, los diccionarios del español continúan recogiendo este tipo de información, en la mayoría de los casos, puramente contextual.

\subsection{La marca 'humorístico' en los prolegómenos de los diccionarios}

Comenzando por la información contenida al inicio del diccionario, las explicaciones que se ofrecen sobre el significado y función de la marca humorístico en los prolegómenos de estos repertorios lexicográficos resultan insuficientes si el objetivo es conseguir que el usuario no solo comprenda el sentido de las distintas acepciones de cada unidad léxica, tal y como aparece recogido en la definición, sino que pueda producir enunciados que se adecuen a la situación comunicativa.

Como ya vimos en el trabajo anterior ya mencionado (Azorín y Santamaría, 2010), por lo que se refiere a la marcación pragmática o connotativa, resaltábamos el escaso número de marcas que se utilizan para trasladar al usuario los matices relacionados con la intención del hablante junto con la falta de homogeneidad en la selección de marcas. En dicho estudio concluíamos con la necesidad de simplificar y unificar el sistema de marcación pragmática en los diccionarios del español con el fin de facilitar su manejo, ya que, como se comprueba en los diccionarios de la muestra, no todos emplean el 
mismo número de marcas ni las mismas para diferenciar los contextos de uso marcados por la valoración del hablante. En la Tabla 1, se recogen aquellas marcas de uso empleadas por los diccionarios revisados que advierten de las intenciones del hablante al usar determinadas piezas léxicas en el listado de etiquetas que aparece en la parte inicial del diccionario.

\begin{tabular}{|l|l|l|l|l|l|l|}
\hline & Salamanca & Alcalá & Espasa & SM & DRAE & DUE \\
\hline Afectivo & afectivo & & & & & \\
\hline Despectivo & & desp. & desp & desp. & despect. & desp \\
\hline Eufemismo & eufemismo & & & euf. & eufem. & \\
\hline Humorístico & humorístico & hum. & & & & hum \\
\hline Insulto & insulto & & & - & & \\
\hline Ironía & ironía & & iron. & & irón. & \\
\hline Peyorativo & peyorativo & & & - & & \\
\hline Ponderativo & & & & & & pond \\
\hline
\end{tabular}

Tabla 1. Marcas pragmáticas usadas

Por lo que se refiere a la marca que nos ocupa, el DUE, el Alcalá y el Salamanca son los únicos que introducen la marca humorístico en la lista de abreviaturas que figura en la parte inicial de los diccionarios.

Si nos fijamos en el diccionario tomado como referencia - DUE- ofrece un número considerable de marcas de registro o valoración, pues junto a las categorías principales que aparecen en el apartado 'Registro y valoración', incluye bajo el epígrafe 'Otras' diversas etiquetas que reflejan la intención del hablante entre ellas, achulado, afectado, afectuoso, brusco, burlesco, burlón, ceremonioso, esmerado, festivo, grosero, hiperbólico, inconveniente, indelicado, irónico, jocoso, ñoño, patético, pulido, reprobatorio, soez, solemne, etc., hasta un total de 30 . En sus páginas iniciales el diccionario explica que se han codificado aquellas intenciones o matices expresivos no deducibles de la definición que se dan mayoritariamente en todos los contextos de uso, aspecto que subrayo porque más adelante comprobaremos que este no parece ser el criterio que se ha seguido. Por tanto, en sus preliminares se muestra como un diccionario que atiende los avances de las teorías pragmáticas actuales, ya que incluye no solo los significados naturales de las unidades léxicas sino también aquellos contenidos implícitos que vienen dados por el uso habitual de una comunidad lingüística y cultural.

En lo que respecta a la marca 'humorístico', el $D R A E$ no incluye esta etiqueta, pero si atendemos a las abreviaturas de nivel de uso que indican la intención del hablante hallamos otros sentidos muy relacionados con el humor como son burla, irónico o festivo, a los que volveré más adelante.

En cuanto a los $D M A$, en el Alcalá figura la etiqueta que sirve para indicar el uso humorístico de una entrada, ya que como indica el diccionario en el apartado «infor- 
mación sobre lenguajes de especialidad, niveles de uso y sentido»: «Este diccionario también ofrece información de naturaleza sociolingüística y estilística en las acepciones que a nuestro juicio lo requieren, si bien somos conscientes de que estos valores no son constantes en toda la extensión del ámbito hispanohablante. A pesar de esta dificultad, el criterio que nos ha guiado siempre ha sido el de proporcionar una información que permita un uso adecuado al contexto en cualquier lugar del mundo hispánico»» (Alcalá: XIV).

El Espasa resulta bastante más parco en los preliminares a la hora de introducir información de estas características. Él mismo indica «este diccionario pretende constituir una herramienta de gran utilidad para el acercamiento a la lengua española, sin pretensiones de exhaustividad en su desarrollo por obvias razones de espacio, pero con las más altas aspiraciones prácticas en lo que se refiere a su corpus léxico seleccionado, sus significativas observaciones de uso y su facilidad de manejo en la consulta» (Espa$s a$ : IX). En cuanto a la información sobre la intención humorística o las marcas que la reflejan no incluye la etiqueta humorístico, pero sí otras relacionadas como irónico.

Muy diferente es el Salamanca considerablemente más explícito en mostrar la intención del hablante que el resto de obras seleccionadas. Como indica en su Introducción es una obra dirigida a «todos los estudiantes, sean o no extranjeros, que quieran mejorar su dominio de la lengua española» (III), de ahí que se esfuerce por incluir un conjunto de marcas claras que permiten usar las palabras en situaciones comunicativas concretas. Por un lado, marcas de uso y registro, las cuales aparecen explicadas, y por otro, marcas pragmáticas que «intentan señalar las posibilidades de uso en ciertas circunstancias de algunas expresiones y términos» (XI), entre las que incluye la marca humorístico. El Salamanca no utiliza abreviaturas, sino que introduce en el apartado correspondiente de los preliminares del diccionario la lista completa de marcas pragmáticas $^{7}$ que va a emplear bajo el epígrafe 'La pragmática'; sin embargo, solo se limita a enumerarlas, presuponiendo que la propia etiqueta es suficiente para que el usuario comprenda la indicación que transmite; éstas, como se advierte en el prólogo: «indican bastante en sí mismas» (Salamanca: XI).

Por lo que se refiere al diccionario para extranjeros de $S M$ indica que «se ha acotado y concretado la utilización de las palabras que tienen un valor determinado. Los valores anticuado (ant.), coloquial (col), eufemístico (euf.), poético (poét.), despectivo (desp.), vulgar (vulg.) y vulgar malsonante (vulg. Malson.)» (SM: 9). No menciona el uso o matiz de una palabra en sentido humorístico.

${ }^{7}$ Incluye el siguiente listado: amenaza, afectivo, afirmación, ánimo, anticipador narrativo, contestación a presentación, despedida, disgusto y enfado, eufemismo, humorístico, infantil, insulto, intensificador, ironía, llamada de atención, negación, petición, peyorativo, presentación, resumidor final, saludo, sorpresa, tratamiento. Si nos fijamos en esta lista, sería conveniente simplificar el sistema de marcas y dar una mayor uniformidad, diferenciando aquellas marcas que muestran la intención o la actitud del hablante (humorístico, irónico,...) de aquellas que tienen un carácter textual (anticipador narrativo, presentación, resumidor final). 
Para concluir este apartado cabría señalar lo ya puesto de manifiesto por numerosos autores; esto es, que los diccionarios del español son poco explícitos en los preliminares de la obra a la hora de aclarar los criterios que se han utilizado para incluir entre sus páginas aquellos significados que muestran valoración o intención por parte de los hablantes. De igual modo los diccionarios revisados muestran una falta de homogeneidad a la hora de utilizar etiquetas pragmáticas, especialmente en el caso que nos ocupa, el sentido humorístico de una voz.

\subsection{La codificación de la marca humorístico y los límites borrosos del humor en el diccionario}

En el DUE 2008 hay 182 entradas marcadas como humorísticas. De estas en 139 (76’37\%) aparece la marca propiamente dicha situada al principio de la acepción. La indicación de humorístico se expresa en la mayoría de los casos mediante la abreviatura hum, excepto en el Salamanca donde aparece la forma completa humorístico, como se puede ver en el ejemplo.

Ejemplo 1: Uso de la marca humorístico

aflojar tr. inf. y hum. Entregar dinero: 'Tendrás que aflojar cincuenta euros. Le cuesta trabajo aflojar la pasta' $(D U E)$.

pandero 2. COLOQUIAL; HUMORÍSTICO. Culo: ¡Vaya pandero, niña! (Salamanca).

El resto de las entradas (23'62\%) corresponden a la presencia de 'en tono humorístico', 'a veces humorístico' en la definición o como nota de uso, aunque de ellas al menos 10 ocurrencias son de carácter metalingüístico como queda registrado en el ejemplo 2 y en el ejemplo 3 respectivamente.

Ejemplo 2: Uso de humorístico como nota de uso

bandido, -a 3 inf. Hombre que engaña o estafa, aunque sus actos no lleguen a constituir delitos penados por la ley: 'En esa tienda son unos bandidos'. 1 *Granuja. 5 A veces, humorístico o afectivo: 'Ese bandido me ha dejado sin cigarrillos' (DUE).

Ejemplo 3: Uso metalingüístico de humorístico

viñeta 3 Cada una de las escenas dibujadas en un tebeo o cómic. 5 Dibujo humorístico o satírico, acompañado generalmente de un pequeño texto, que aparece en algunas publicaciones; en particular, en periódicos y revistas $(D U E)$. 
Se observa que la indicación de humorístico se expresa de forma asistemática mediante diversos procedimientos, lo que implica que no se ha conseguido una codificación adecuada de este significado intencional en los diccionarios del español; primero, porque no siempre está presente esta etiqueta valorativa en los diccionarios; segundo, porque aquellas palabras que pueden adquirir este sentido figurado no siempre están codificadas con ella; y por último, porque se emplean etiquetas distintas para sancionar usos interpretativos similares. Así, si buscamos en el diccionario académico el significado de la voz humorístico, nos dice:

humorístico, ca. 1. adj. Perteneciente o relativo al humorismo de la expresión o del estilo literario.

humorismo.1. $\mathrm{m}$. Modo de presentar, enjuiciar o comentar la realidad, re-

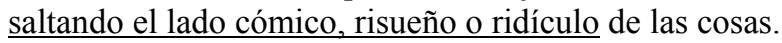

Atendiendo a esta definición lexicográfica, cuando se etiqueta una palabra o expresión con la marca humorístico, se le está informando al usuario de la obra que dicha voz representa un referente de la realidad en el que se resalta su lado cómico o al menos que su empleo es capaz de generar una sonrisa entre los hablantes. Por tanto, una voz como sablazo, presente en todos los diccionarios de la muestra, está marcada como humorístico en el $D U E$, pero en el resto de los repertorios revisados no se emplea esta etiqueta para señalar este valor o contenido: o bien se sanciona mayoritariamente como coloquial (DRAE, Espasa, Salamanca, SM), o bien como familiar (Alcalá). Ante esta situación lexicográfica, ¿qué información puede extraer un consultante extranjero? ¿En qué situaciones sablazo se utiliza para resaltar el lado cómico, risueño o ridículo de las cosas?

$\mathrm{Si}$ analizamos los diccionarios revisados, comprobamos que estos presentan otras etiquetas referidas a otros conceptos relacionados semánticamente con la categoría del humor, lo cual es indicativo de la dificultad a la hora de describir y sistematizar este fenómeno verbal de carácter semántico-pragmático.

Por un lado, encontramos una serie relacionada con etiquetas referidas a mostrar una intención de burla por parte del hablante: burlesco, burla, burlón.

burla. 1. f. Acción, ademán o palabras con que se procura poner en ridículo a alguien o algo.

burlón, na. 1. adj. Inclinado a decir burlas o a hacerlas. U. t. c. s. 2. adj. Que implica o denota burla.

burlesco, ca. 1. adj. coloq. Festivo, jocoso, sin formalidad, que implica burla o chanza. 
Otra marcación empleada para codificar este sentido adicional es la de festivo, jocoso o irónico. ${ }^{8}$

festivo, -a [...] 2 adj. Hecho para hacer reír o hacer gracia: 'Un semanario festivo. Hablar en tono festivo'. 1 Humorístico. 2 *Cómico.

jocoso, -a. adj. Se aplica a las cosas que se dicen sin seriedad, con una mezcla de *broma y *burla.

Atendiendo a las definiciones de estos conceptos que nos ofrece el diccionario académico hemos subrayado aquellas partes que muestran que, cuando sancionamos una voz con alguna de estas etiquetas, le estamos comunicando al usuario de dicho repertorio lexicográfico que son palabras usadas con un intención determinada, o bien para hacer reír o bien para hacer gracia, con intención positiva, esto es, crear un ambiente cordial y de solidaridad entre los hablantes, o con una intención negativa al poner en ridículo al oyente y utilizarse como burla. Con ello se observa que no existe una única marcación posible que recoja este significado intencional, por lo que uno de los objetivos que deberían tener los diccionarios es delimitar de una manera más clara las diferencias entre estos conceptos y homogeneizar las distintas etiquetas en una anotación de uso más clara y efectiva para los destinatarios, especialmente para los aprendientes de español como segunda lengua. En los diccionarios analizados se emplean marcaciones como humorístico, irónico, festivo, jocoso, burlesco, etc. que nos sitúan en el mismo eje semántico, el del humor, pero que conforman un continuum de límites borrosos que poco o nada ayudan a un estudiante extranjero. Pensamos que etiquetas como burla o humorístico o mejor anotaciones de uso como se usa con intención de burla o se usa con intención humorística pueden ser más comprensibles para este tipo de destinatarios. Otra cuestión es si la marca humorístico es realmente necesaria en los diccionarios como se irá viendo a lo largo de este trabajo.

Volviendo a la presencia de la marca 'humorístico' u otras relacionadas, en el DUE encontramos, además de las 139 sancionadas con humorístico, 9 voces marcadas como burlesco: emperejilar, güito, peripuesto-a, popa, retrónica, sopitipando, soplado-a, superferlítico-a, ternerón; 2 ítems sancionadas con la etiqueta burlón: limpión-a, modoso-a; 2 etiquetadas como festivo: aindamáis, levosa; y finalmente 28 como jocoso:

\footnotetext{
${ }^{8}$ No hemos incluido en este trabajo la marca 'irónico' pese a la estrecha relación que existe entre ambos fenómenos verbales - ironía puede entenderse como un tipo de humor (Hidalgo e Iglesias, 2009) - porque existen varios trabajos dedicados a la codificación de esta marca en los diccionarios españoles (Garriga, 1996 y Marimón, 2005). Para Attardo (2001: 169) la ironía es un fenómeno exclusivamente pragmático, en el que funciona la activación de inferencias, mientras que el humor es un fenómeno semántico (en el que se produce una incongruencia entre dos marcos) y pragmático (que supone la violación del principio de cooperación de Grice). Tanto la ironía como los juegos (humorísticos) pueden emplear las incongruencias, aunque en el caso de la ironía no se encuentran presentes los dos sentidos o marcos en el texto como vimos que ocurría en el humor.
} 
algo (ir a dar algo), calvario, carricoche, coruscante, dueño-a, gorigori, guijar, jindarra, juanete, milagro, monada, non plus ultra, parlar, pata 1, pecador-a, peñaranda, pozo, ratón, renunciar, sapiencia, sapiente, señor-a, sesudo-a, sueño, tela 1, tizonazo, tiriquitraque, yugo.

El DRAE no incluye la etiqueta 'humorístico', pero si buscamos en las abreviaturas de nivel de uso que indican la intención del hablante, hallamos la marcación 'burla' (U. en son de burla) (1); festivo o U. en sentido festivo (116) o irónico (137). Si nos atenemos al corpus de voces humorísticas que hemos creado, comprobamos que en algunas entradas sancionadas como humorísticas en nuestro diccionario de referencia, en el diccionario académico se emplean otras marcas. De este modo se emplea la etiqueta festivo en 14 entradas de las que conforman nuestro corpus de voces humorísticas ${ }^{9}$ : camota, charrasca, charrasco, chela, chimbo, cultalatiniparla, cultedad, cultería, cultero, esterar, fauna, flojeritis, naso, templete; dos notas de uso que indican que U. para designar despectiva o humorísticamente (de marras) y U. para indicar su carácter ridiculo (poema).

Por lo que respecta a los $D M A$, en el Espasa no figura ninguna de estas etiquetas en la selección de voces estudiada, pero hemos hallado una voz fémina con una nota de uso 'suele usarse en tono humorístico'. El diccionario $S M$ tampoco hace constar ninguna de estas categorías relacionadas con el sentido humorístico, pero sí incluye 9 entradas de nuestro corpus con una nota de uso que indica que dicha acepción tiene un matiz humorístico. Finalmente, el Alcalá sanciona, como hemos visto, este significado en las abreviaturas empleadas, pero no figura en ninguna de la muestra empleada según los datos obtenidos.

Esta diversidad de etiquetas empleadas en los diccionarios para marcar algunas voces cuyo significado codificado adquiere un sentido cuya intención es provocar la risa o la sonrisa del receptor ya sea como simple juego, como crítica o como provocación es difícil de analizar pues se emplea de forma poco clara. Así, si seleccionamos algunas unidades léxicas de nuestro corpus de voces humorísticas, comprobaremos lo dicho:

- O aparecen con otros valores, por ejemplo peyorativo o despectivo o irónico.

\begin{tabular}{|c|c|c|c|c|c|}
\hline$D U E$ & $D R A E$ & Salamanca & Alcalá & Espasa & $S M$ \\
\hline bodorrio & $\mathrm{Col}$ & col pey & no & Desp & col desp \\
\hline de marras & $\begin{array}{l}\text { U. para designar } \\
\text { despectiva o } \\
\text { humorística- } \\
\text { mente }\end{array}$ & Col, peyor, hum & Fam desp & $\begin{array}{lr}\text { Suele } & \text { usarse } \\
\text { con } & \text { sentido } \\
\text { desp o irónico }\end{array}$ & col \\
\hline
\end{tabular}

Tabla 2. Entradas con marca humorístico $u$ otras

${ }^{9} \mathrm{Si}$ se procede a la búsqueda de esta etiqueta en el $D R A E-2001$, se obtiene un total de 108 ítems léxicos marcados como festivo. 
- O en unos diccionarios sí está dicha voz marcada con un uso humorístico y en otros repertorios no se incluye dicha unidad.

\begin{tabular}{|l|l|l|l|l|l|}
\hline DUE & DRAE & Salamanca & Alcalá & Espasa & SM \\
\hline bwana & no & no & no & no & $\begin{array}{l}\text { col Su uso tiene } \\
\text { un matiz humorís- } \\
\text { tico }\end{array}$ \\
\hline mamitis & no & Col. hum. & no & no & $\begin{array}{l}\text { col tiene un matiz } \\
\text { humorístico }\end{array}$ \\
\hline pitopausia & no & no & no & no & $\begin{array}{l}\text { col tiene un matiz } \\
\text { humorístico }\end{array}$ \\
\hline
\end{tabular}

Tabla 3. Presencia o no de entradas con marca humorístico

\subsection{Palabras con la marca humorístico en los DMA}

En esta sección prestaremos atención a aquellas unidades léxicas marcadas con la etiqueta humorístico en el diccionario de referencia con la intención de analizar qué tipo de unidades o expresiones suelen ir precedidas por esta etiqueta sancionadora.

De las 139 entradas que se recogen en el $D U E$ con la marca hum., la mayoría son unidades léxicas simples. Hallamos 20 unidades complejas que aparecen como subentradas de muy diversa índole: desde refranes o dichos populares (servir lo mismo para un barrido que para un fregado, no parecer costal de paja, tener siete vidas como los gatos) pasando por locuciones de diferentes características (para el arrastre, hacer el barbo, llevar la cesta, tener vuelta, faltaría plus, ni hablar del peluquín) hasta expresiones publicitarias como la prueba del algodón, etc.

Partiendo de las voces humorísticas extraídas del $D U E$, las hemos comparado con el resto de diccionarios seleccionados con el fin de comprobar si existe un criterio homogéneo a la hora de etiquetar como humorística una determinada voz. Los resultados pueden verse en la Tabla 4 y representadas gráficamente en el Gráfico 1.

\begin{tabular}{|l|l|l|l|l|l|}
\hline & Salamanca & Alcalá & Espasa & SM & DRAE \\
\hline Sí con marca hum. & 14 & 1 & 0 & 0 & 13 \\
\hline No está & 74 & 100 & 94 & 82 & 35 \\
\hline Sí, no acepción & 18 & 17 & 18 & 12 & 24 \\
\hline Sí, sin marca & 6 & 4 & 8 & 6 & 19 \\
\hline Hum. notas de uso & & & 2 & 9 & 2 \\
\hline Otras marcas de uso & 27 & 17 & 17 & 30 & 46 \\
\hline
\end{tabular}

Tabla 4. Presencia de voces con marca humorístico 


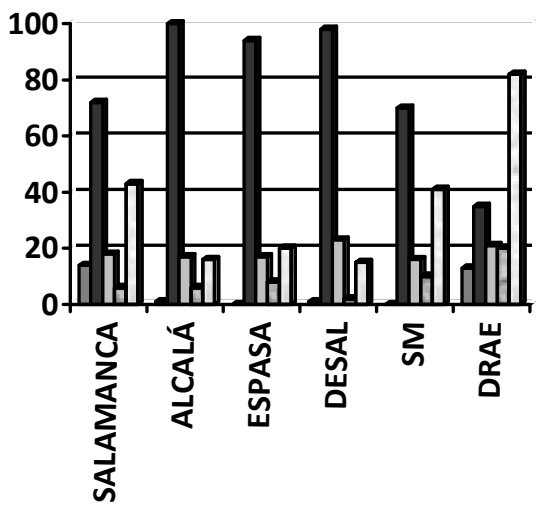

\begin{tabular}{|l|}
$\square S I$ \\
$\square N O$ \\
$\square N O$ ACEP. \\
$\square$ SIN MARCA \\
$\square O T R A S$ MARCAS
\end{tabular}

Gráfico 1

Tras los resultados obtenidos después del análisis contrastivo, están presentes en todos los diccionarios solo 29 voces de las 139 (20'86\%) que conforman nuestro corpus de léxico humorístico, aunque no todas con dicha etiqueta ni con dicha acepción: aflojar, apéndice nasal, para el arrastre, asesino-a, hacer el barbo, bípedo, ciencia infusa, chupatintas, cofradía, comadre, concilio, cónclave, costilla, fauna, fémina, galán, inclito, infante-a, maestro, de marras, menda, personal, pitoniso, poema, radio macuto, receta, sablazo, susodicho, volcánico. Por otra parte, hay un total de 15 entradas que no figuran en ninguno de los otros diccionarios contrastados. Son el cine de las sábanas blancas, dama de los pensamientos, ir a darle algo, desfacedor de entuertos, labores propias de su sexo, macho ibérico, mierdica, number one, pasión volcánica, plis, la prueba del algodón, putiferio, quimbo, de infeliz recordación, vulgaris. Algunas por su uso anticuado como labores propias de su sexo; otras por ser extranjerismos sin adaptar (number one) o ya adaptados (plis). Otras como dama de los pensamientos, de infeliz recordación son difíciles de descubrir su intención humorística, o al menos es difícil comprobar este matiz en todos los contextos de uso en los que se emplean, como manda o recomienda la técnica lexicográfica.

Un porcentaje considerable (30-40\%) de las voces seleccionadas se combinan con otras marcas que restringen el uso, generalmente coloquial (DRAE, Salamanca, Espa$s a, S M)$. En el $D U E$ se emplea en su lugar la etiqueta informal mayoritariamente (aflojar, antiparras, para el arrastre, bwana, caquéctico, llevar la cesta, macho ibérico, etc.) y en otras la marcación popular (ajuntar, cagatorio, calza, comadres, personal, etc.). En el Alcalá la marca humorístico se combina con la etiqueta de nivel de uso familiar equivalente en el sistema de marcación a la marca coloquial del resto de los diccionarios.

De los repertorios lexicográficos analizados el diccionario Salamanca es el que más voces sanciona con intención humorística (14): costilla, dolorosa, fémina, galán, mamitis, de marras, menda, meódromo, mojamé, mundología, paganini, radio macuto, 
romeo, zarpa. No obstante, si atendemos a los resultados de otros trabajos anteriores como el de Guerra Salas y Gómez (2005: 359-360) que analizan las marcas pragmáticas en esta obra, aunque los autores no explican cómo las han extraído, se comprueba que hay bastantes más formas léxicas que cuentan con la marca pragmática humorístico entre ellas calabaza, degollar, rosco, fiambre, rajá, manteca, feligrés, fideo, teniente, libar, pandero, castaña, tostadero, destetar, muerdo, paganini, pagano, bebercio, chupóptero, cabronicie; algunas voces de argot (militroncho, rancho) y numerosas frases y locuciones, del tipo como año de la nana/pera/de Maricastaña, hacer patria, si las matemáticas no fallan, vivir como un patriarca, deshacer un entuerto, casarse de penalti, cortarse la coleta, cantar el kirieleisón, menear el bigote, estar lquedarse de Rodríguez, secarse el cerebro, tener espolones, por amor al arte, con la música a otra parte, guay del Paraguay, las cuales no forman parte de nuestro corpus.

De igual modo se comporta el diccionario Alcalá en el que el grado de coincidencia de voces humorísticas con el corpus seleccionado es mínimo, aunque también la etiqueta humorístico se encuentre entre las usadas. Así, de todas las voces que constituyen nuestro corpus de voces léxicas del humor, en el Alcalá solo aparece sancionada la unidad léxica radio macuto. La mayoría no están, y las que se incluyen están marcadas como familiar. No obstante, en el listado de abreviaturas está presente esta etiqueta sancionadora de la intención del hablante, lo que demuestra que ciertos aspectos del significado son difíciles de codificar en los diccionarios, porque están supeditados a la subjetividad del autor del repertorio.

Cabe destacar que el diccionario de $S M$ incluye esta información como nota de uso 'tiene un matiz humorístico' tras la definición en 9 ocurrencias: antiparras, bwana, cornúpeta, cuentitis, mamitis, missing, mundología, pitagorín, pitopausia.

\section{Ejemplo 4}

mamitis s. f. col. Apego desmesurado a la madre USO Tiene un matiz humorístico

Por lo que respecta al Espasa ya hemos visto que no incluye esta marca pragmática, pero en la selección léxica humorística hay una voz que lleva una nota de uso al final de la acepción.

\section{Ejemplo 5}

Fé-mi-na f. Mujer, persona del sexo femenino: Dicen que es una revista para féminas, pero la leen muchos hombres. Suele usarse en tono humorístico. 


\subsection{Información sobre el sentido humorístico en el artículo lexicográfico}

Con respecto a la definición de estas entradas, nos fijaremos en primer lugar en nuestro diccionario de referencia, el $D U E$, donde podemos encontrar una serie de casos en los que en la definición se indica el sentido recto, natural o literal acompañado de la marca humorístico, sin especificar en qué contextos comunicativos se puede emplear con los consiguientes problemas para el usuario del diccionario que no tenga una competencia comunicativa suficiente: antiparras, costilla, concilio, hisopo, llevar la cesta, pecar, soconusco, mojado. Sirvan como muestra los siguientes.

\section{Ejemplo 6}

costilla (del lat. costa) [...]. 5 hum. Con respecto a un hombre, su *mujer.

mojado, -a [...]. 2 hum. Abatido.

En ocasiones más que definiciones son explicaciones de su uso o indicaciones de cuándo se aplica dicho sentido, lo cual resulta de mayor utilidad para el consultante extranjero del diccionario.

\section{Ejemplo 7}

maestro, -a (del lat. magister, -tri) [...] 6 pop., gralm. hum. También como *apelativo para dirigirse a cualquier persona.

poema (del lat. poèma, del gr. poíèma) [...] 3 hum. (n. calif.) Se aplica a un suceso o escena en que hay poesía: 'Sus amores fueron un poema'. 5 También, humorísticamente, a acciones o escenas que encierran comicidad: 'La despedida de las dos cuñadas fue todo un poema'.

Algunas de estas explicaciones o indicaciones de uso son de carácter enciclopédico

Ejemplo 8

dictablanda (forma festiva de dictadura, con falso corte etimológico). f. hum. Dictadura poco rigurosa. Se aplica especialmente al gobierno del general Dámaso Berenguer (1930-31), que siguió a la dictadura de Primo de Rivera.

patafísica (del fr. pataphysique, compuesto festivo a partir de épi- y [mé]taphysique) f. Liter., hum. Ciencia de las «soluciones imaginarias» inventada por el rey Ubú, personaje de las obras del escritor francés Alfred Jarry (1873-1907).

Otros casos son aquellos que con la sola indicación de 'generalmente hum.' o 'frecuentemente hum.' se espera que el usuario deduzca cuál es el contexto adecuado para 
usar dicha voz en sentido humorístico: servir lo mismo para un barrido que para un descosido, boricua, latir el corazón, coyunda, fémina, enseñorearse, romeo, de tiros largos, tortolito, ser una enciclopedia viviente, galán, pasión volcánica, pero sin ejemplos ni otra información de uso, con lo cual es el usuario del repertorio lexicográfico el que tiene que decidirse por adjudicar ese sentido o no según el contexto en el que se emplea, lo que no resulta fácil porque pueden interpretarse tanto en sentido humorístico como en su uso denotativo. Sirvan como muestra los siguientes casos:

\section{Ejemplo 9}

boricua adj. y n. gralm. hum. Puertorriqueño.

latir el corazón por alguien gralm. hum. Sentir *amor por la persona de que se trata.

romeo $^{1}$ (de Romeo, nombre del personaje de la tragedia de Shakespeare, que forma con Julieta una de las parejas de amantes célebres) m. gralm. hum. Hombre enamorado.

Así, ante un enunciado como el siguiente: «Al atardecer de este martes, hora de España, dejó de latir el corazón del gran bailarín y coreógrafo de 67 años de edad» [CREA, 14/03/2011] el receptor debe recuperar el significado literal de la expresión latir el corazón, muy poco humorística en este contexto.

Algunas de las definiciones aparecen en cursiva, para indicar que son significados poco usuales, por tratarse de acepciones muy restringidas, raras o no documentadas.

Ejemplo 10

esterar 1 tr. Recubrir de esteras el suelo de una habitación. 2 (reflex.) hum. Vestirse de invierno.

fililí (de filelí) m. inf. y hum. Delicadeza, refinamiento, sutileza o primor con que está hecha o trabajada una cosa.

filustre (de filis y lustre) m. inf., hum. Finura o elegancia.

En segundo lugar, dedicaremos nuestra atención a comprobar si los diccionarios monolingües de ELE son más explícitos a la hora de dar esta información favoreciendo el desarrollo de la competencia pragmática de sus destinatarios.

Empezando por el diccionario que más voces sanciona como humorísticas, el Salamanca advierte de su uso mediante etiquetas completas, da una definición sinonímica o perifrástica y finalmente, un ejemplo de uso que favorece la comprensión del lema.

Ejemplo 11 
costilla 4. COLOQUIAL, RESTRINGIDO, HUMORÍSTICO. Esposa: No tomaré ninguna decisión sin contar con mi costilla.

radio macuto COLOQUIAL HUMORÍSTICO. Emisora de radio que no existe, y a la que se atribuyen los rumores o las noticias por confirmar: Según radio macuto, el profesor se va del colegio.

Con respecto al diccionario Alcalá, únicamente figura la voz radio macuto de todas las de la muestra y emplea etiquetas abreviadas que informan sobre el uso de la entrada, una definición clara y un ejemplo de uso.

Ejemplo 12

radio macuto fam. hum., lugar imaginario desde el que se emiten rumores o cosas sin importancia: me he enterado de su embarazo por-macuto.

El diccionario $S M$ introduce un ejemplo después de la definición y a continuación una nota de uso donde se indica un matiz de significado.

Ejemplo 13

pitopausia s. f. col. Andropausia: Tiene cincuenta años pero no reconoce que está en la pitopausia. Tiene un matiz humorístico.

En definitiva, los diccionarios monolingües de ELE contribuyen de una manera más eficaz al desarrollo pragmático de los estudiantes no nativos de español porque incluyen siempre un ejemplo de uso y una definición sinonímica o perifrástica más transparente, no porque el empleo de la marca humorístico sea más informativa ni sea empleada con un criterio más sistemático u homogéneo. Con respecto a las notas de uso que incluyen algunos de los diccionarios revisados no presentan ninguna explicación en relación con la forma de interpretar el sentido humorístico, con lo cual es también el usuario del diccionario el que debe decidirse por una interpretación literal o connotada de esa voz. En consecuencia, el autor del diccionario debe actuar con precaución a la hora de marcar una palabra o expresión como humorística, pues, como se puede ver con los ejemplos, estamos ante un significado contextual muy marcado por la intención del hablante, y no un significado codificado o gramaticalizado.

Si nos fijamos en los lemas marcados como humorísticos en los DMA resulta bastante complejo determinar qué criterios ha empleado el lexicógrafo para sancionar estas unidades, independientemente de que cada autor selecciona y etiqueta de forma diferente de acuerdo con los datos obtenidos y que se pueden ver en la Tabla 4.

Si para que algo sea considerado humorístico es imprescindible que se perciba el choque o la contradicción entre el enunciado y la realidad, esto es, entre dos espacios mentales que conviven o se sustituyen, es evidente que no todas las palabras y expresiones realizan esta función con la misma intensidad, es más, en muchas de ellas este choque queda minimizado y en consecuencia, también queda reducida la fuerza o la intensidad del efecto humorístico. Desde este punto de vista podemos establecer varios 
grupos de palabras y expresiones marcadas como humorísticas de acuerdo con la selección obtenida de nuestro corpus léxico humorístico.

Hay un grupo de palabras que adquieren este efecto humorístico porque son extranjerismos, préstamos de otras lenguas (missing, number one, bwana) o con alguna modificación fónica (plis de please). En ocasiones son palabras inventadas que reproducen la fonética de otras lenguas (mojamé). Todas ellas suponen un choque o llamada de atención cuando se insertan en un enunciado en español produciendo un efecto humorístico como en el siguiente ejemplo de una crónica deportiva donde se emplea la voz missing como crítica para resaltar el estado ausente o fuera de partido de un jugador. $^{10}$

La segunda parte fue un horror. Antic metió a Vizcaíno para refrescar el medio campo, pero aquello no funcionaba. El Atlético no encontraba ningún motivo por el que meterse en el farragoso camino de la victoria y el Athletic, con el botín conseguido con sólo asomar la cabeza, se daba por más que satisfecho.

No fue de extrañar pues que el partido discurriera con rapidez por el tobogán de la inanición. Los bilbaínos cedieron metros, agruparon aún más sus filas y le dejaron todo al Atlético, que dominó más por la inercia del encuentro que por los escasos méritos que ponía sobre el terreno de juego. Deambulaba Kiko, peleado con un corpachón similar al suyo, el de Karanka, y Esnáider se diluía minuto a minuto. Con Pantic de nuevo "missing" (a los quince minutos de partido ya le pesaban hasta las pestañas), el equipo acusó una fatiga que no le es desconocida en los últimos meses de competición.

Ganó el partido porque fue el único que tuvo un mínimo interés en ganarlo. El Athletic había tenido alguna opción en la primera mitad, con los balones cruzados que ponía a la espalda de la defensa local pero, con los metros perdidos para meterse aún más en su coraza, hasta esta pequeña añagaza acabó perdiendo. Entonces llegó el gol de Kiko, más por proximidad al área rival que por otra cosa, pues el tanto llegó en un córner que el jerezano remató en una postura inverosímil y con la oreja, mientras que Echeberría hacía el Tancredo con la enésima salida a por uvas.

REAL ACADEMIA ESPAÑOLA: Banco de datos (CREA) [en línea]. Corpus de referencia del español actual. $<$ http://www.rae.es $>[12 / 03 / 2011]$

Otras veces son usos humorísticos que se basan en el empleo de un estilo o registro distinto al del enunciado en el que se insertan como mamitis o cuentitis tomados del lenguaje infantil y que emplean un sufijo -itis característico del ámbito de la Medicina.

Al día siguiente igual. No, miento, no obstante me dijo el médico: bueno, pero mañana vienes, te haces un análisis de sangre y estás tranquilo. Fui al especialista del aparato digestivo y nada más verme me dijo que tenía, o sea, apendicitis, ¿no? Y ese mismo día me operaron. $\mathrm{O}$ sea, un fallo lo puede tener cualquiera, de todas

${ }^{10}$ Ha resultado complicado encontrar ejemplos reales en el CREA: algunos porque no existían referencias en el corpus como mojamé o plis; otros porque no se usaban en contextos humorísticos. 
formas, lo que es aquí urgencias, o sea, hablando en plata, es una mierda yo he visto Muchos casos aquí fuertes. Sí. A una amiga por apendicitis le dijeron que era cuentitis, le dijeron que era cuentitis para no ir al colegio. Mira yo cuando Hasta que fue a un especialista y le dijo que tenía una apendicitis, que había que operarle urgentemente. Yo, por ejemplo o sea, yo, el jueves se luego se lo comenté a mi madre, porque yo esto no yo soy muy aprensiva y a mí no me gustan los hospitales, pero, entré, y claro, entras y tienes que esperar hasta que te llamen. Entonces, estaba en la sala, pues nada, había un señor que estaba totalmente desangrándose y que decía que el médico bueno, se estaba quejando porque el médico le había dicho que no era importante. Había llegado a su casa y la barriga se le había reventado. Yo estaba al lado y yo diciendo: socorro, mi ojo puede esperar. Total si le hago un yo qué sé, lo que sea.

La voz cuentitis es propia del lenguaje infantil, porque suelen ser los niños los que fingen enfermedades para no ir al colegio; por lo tanto, el hecho de que esta sea empleada por un adulto puede tener efectos humorísticos o al menos provocar una sonrisa en el interlocutor. Además estamos ante una unidad léxica que imita los términos médicos, pues está formada por la base léxica cuent(o) más un sufijo -itis 'inflamación' muy frecuente a la hora de denominar enfermedades (apendicitis, otitis, faringitis, amigdalitis, etc.). Esta trasposición es lo que puede tener consecuencias humorísticas.

A veces se reproduce una forma latina: vulgar-vulgaris para dar un carácter culto al enunciado.

- Si dentro de 30 días no las tengo en mi poder acudiré al juez.

- ¿Esto quiere decir que también va a denunciar a José María Calviño?

-Consultaré con mi partido y después iré al juzgado y denunciaré los hechos. No es lógico que ahora no me lleguen las facturas y antes sí, por eso pienso que los que estaban con Miró no eran sus amigos pero sí lo son de Calviño.

- Pero para usted fue un éxito político su actuación en el caso Miró, ¿o no fue así?

-Efectivamente, para mí pudo ser un éxito, pero no me resultó nada grato. Le tengo una gran simpatía porque tuvo la valentía de no volver la cara nunca.

- ¿Existe alguna relación entre el caso de Pilar Miró y el caso de Juan Guerra?

-El de éste es el caso de un chorizo vulgaris, pero la gran paradoja es que lo que él ha hecho, gracias a los socialistas no está penalizado y esto me produce una gran zozobra.

REAL ACADEMIA ESPAÑOLA: Banco de datos (CREA) [en línea]. Corpus de referencia del español actual. $<$ http://www.rae.es> [09/03/2011]

La palabra vulgaris se forma a partir del adjetivo vulgar al que se le añade el sufijo -is, reproduciendo la forma culta latina vulgaris 'del vulgo' que combinada con chorizo 'ladrón de poca monta' y vulgar tiene un efecto humorístico.

En ocasiones son usos restringidos al ámbito literario o culto, de ahí que su uso en otro tipo de enunciado pueda tener un matiz humorístico. Son casos como fémina, galán, romeo.

En vísperas de casarme tuve una bronca con mi suegra... Ella se subió a la parra y empezó a decirme: "Pero tú ¿qué te has creído? Tú no eres más que un chico, un chico de nada que se 
casa con la hija de unos reyes...” Y ya se me hincharon las narices y le dije: “¡Un momento...! No se trata de andar aquí sacando los padres y los abuelos a relucir. Pero si te pones así tendré que recordarte, querida tía Freddy, aunque mis padres no estén reinando, soy nieto de reyes, y con bastantes expectativas de llegar a ser el Rey de España..." Le dije que yo no era un don nadie. Que yo era alguien.

¿Apasionadamente? Yo no soy un hombre que se enamore apasionadamente, perdidamente. (El Rey hace una imitación burlona de un romeo de ojos en blanco y ohohoh) Aparte de que, entre ella y yo hablábamos en inglés. En inglés, oye, y a mí el inglés no es precisamente lo que más me... Vamos, que no es un idioma que me inspire y apasione.

REAL ACADEMIA ESPAÑOLA: Banco de datos (CREA) [en línea]. Corpus de referencia del español actual. $<$ http://www.rae.es> [09/03/2011]

La voz romeo hace referencia a un hombre enamorado como lo fue el personaje de Shakespeare, un enamoramiento que puede llegar a resultar cómico por su sentido hiperbólico pese a ser trágico en su origen.

En un grupo numeroso de entradas marcadas como humorísticas este sentido viene dado por el uso de ciertos prefijos, sufijos o formantes cultos que modifican el significado de la base léxica tales como:

— pitagorín (-in sufijo diminutivo que se añade a la base Pitágoras (matemático): Se trata de alguien que no llega a ser un gran sabio, pero que se cree como tal.

— mundología (mundo + logía 'ciencia'): El conocimiento del mundo no es una ciencia.

—pitopausia (pito 'pene' + pausia 'cesación'): Por analogía con menopausia y frente al término médico andropausia, popularmente se utiliza esta voz para referirse a la edad del hombre en que cesa la actividad testicular.

— meódromo (meo 'mear' + dromo 'carrera'): Se trata de un lugar destinado a orinar.

- dictablanda (dictadura + blanda): Es una dictadura pero ridícula.

- paganini (pagano 'que paga' + -ini 'sufijo para formar gentilicios en italiano').

De esta índole son muchas voces de las que hallamos en nuestro corpus: bodorrio, cagatorio, camota, critiquizar, cultalatiniparla, cultedad, cultería, cultero, cultiparlar, dedocracia, flojeritis, fregatriz, futbolero, mierdica, patafísica, putiferio, entre otras. En realidad, son palabras y expresiones cuyo significado se utiliza para ridiculizar o mencionar burlescamente aquello a lo que se refieren dando lugar a enunciados con un tono despectivo, depreciativo y burlesco.

Otras veces las voces marcadas como humorísticas tienen su base en una metáfora como (la) dolorosa 'cuenta o factura que hay que pagar' o metonimias del tipo costilla 'mujer' por referencia bíblica, las cuales pueden adquirir connotaciones negativas como chupatintas o un significado hiperbólico como bodorrio.

Como podemos ver a través de los ejemplos analizados, son palabras o expresiones que cargan de afectividad y emociones los enunciados en los que se insertan, y por tanto, añaden un importante efecto modalizador ante lo que se dice. Cuando el hablante 
selecciona estas unidades léxicas impregna de intenciones su enunciado y ello obliga al receptor a elegir una de entre varias posibles interpretaciones, casi siempre la de ridiculizar o burlarse de aquello a lo que se refieren, y al mismo tiempo distanciarse y protegerse de su propio enunciado. Pero ello implica por parte del destinatario un mayor esfuerzo inferencial para alcanzar la comprensión de dicho enunciado.

En definitiva, es difícil trasladar este significado contextual a los diccionarios, pero al mismo tiempo es necesario que se incluyan para facilitar la comprensión o interpretación de los enunciados que van más allá de la acepción denotativa de las palabras, y cuyo significado depende del contexto e intenciones del hablante, del conocimiento que comparten hablante y oyente, etc. De ahí que resulte difícil etiquetar los significados intencionales como el humor en un diccionario.

Siguiendo a Ruiz Gurillo (2009: 373) y trasladando sus palabras a nuestro objeto de estudio, el humor, al igual que ocurre con otros fenómenos verbales como la ironía, se puede llegar a gramaticalizar en algunos casos (Traugott y Dasher, 2002); ${ }^{11}$ esto es, partiendo de las teorías neogriceanas (Levinson, 2000), el significado 'humorístico', como fenómeno puramente contextual, se infiere por una implicatura conversacional particularizada (ICP) la cual se ha ido generalizando con el paso del tiempo hasta convertirse en un significado codificado y con su aparición en determinados contextos se convierte en una implicatura conversacional generalizada (ICG), de tal forma que la presencia de estas palabras en un enunciado es suficiente para detectar el sentido humorístico.

Después del análisis de las voces humorísticas de nuestro corpus se observa que existe una gradación a la hora de expresar la función humorística. Algunas voces cumplen claramente esta función al haber incorporado dicho significado al código lingüístico, mientras que otras dependen del contexto en el que se inserten. Solo aquellas voces donde el significado intencional quede claro deberán figurar en el diccionario. Además tras el análisis de nuestro corpus de voces humorísticas se puede concluir que aquellas voces que podrían sancionarse con esta marca, deberían llevar la etiqueta de burla o una nota de uso que indicase que 'se usa con intención de burla' pues es este el efecto perseguido mayoritariamente en las palabras estudiadas, y en nuestra opinión, una sanción más clara para los estudiantes no nativos.

\section{CONCLusiones}

Tras el repaso a los sistemas de marcación del sentido humorístico podemos concluir que la codificación de este significado intencional no puede quedar supeditado a criterios subjetivos de los autores de las obras lexicográficas como se desprende del estudio realizado. En este sentido hemos observado:

\footnotetext{
${ }^{11}$ El objetivo principal de la Teoría del cambio semántico a partir de las inferencias asociadas es explicar la convencionalización de los significados pragmáticos y su reanálisis como significados semánticos.
} 
1. Diversos procedimientos de marcación y distintas etiquetas (humorístico, burla, festivo, jocoso,...) para referirse a este concepto semántico;

2. Un conjunto heterogéneo de palabras marcadas como humorísticas, y en las que es difícil determinar cuáles son los criterios que llevan a los autores del diccionario a sancionar con la etiqueta humorístico una unidad léxica.

Así, las formas que cuentan con la marca pragmática humorístico presentan una gran variedad en cuanto a los mecanismos que se emplean para la creación de este efecto. Por un lado, se recurre a la traslación de sentido (costilla, dolorosa, receta, zarpa, personal); por otro, a extranjerismos reales o inventados (bwana, plis, missing, mojamé), a cambios de registro (mamitis, megatriz, romeo, dulcinea) y especialmente a asociaciones basadas en la semejanza de los significantes mediante la adición de afijos (paganini, vulgaris, meódromo). Se asumen como humorísticas palabras modalizadas que no son siempre estrictamente humorísticas sino que dependen de las intenciones comunicativas de los hablantes. En la mayoría de los casos estas expresiones son de difícil comprensión para un usuario sin competencia plena, tanto por la falta de contextualización como por las definiciones, aunque en los diccionarios monolingües de ELE incluyan ejemplos de uso que facilitan el proceso de decodificación.

Tras el análisis realizado, insistimos, en la necesidad, como han apuntado otros autores, de perfeccionar los sistemas de marcación, especialmente en el caso de los diccionarios didácticos, yendo hacia propuestas de señalización más simples y explícitas tomando como modelo las notas de uso ('es humorístico en una determinada situación' o 'es humorístico cuando se aplica a', etc.) frente a la marca humorístico, abreviada o no, que necesita de la colaboración de los usuarios que tienen que leer y entender las instrucciones de uso.

De igual modo el estudio de las voces humorísticas seleccionadas nos permite concluir que la mayoría de ellas son palabras que tienen como función principal burlarse o ridiculizar el elemento al que se refieren; por tanto, sería más efectivo dar cuenta de esta intención más delimitada y transparente para los estudiantes extranjeros que la de humorístico, que resulta un concepto menos fijado lingüísticamente y muy determinado por el contexto.

No obstante, no se puede echar toda la culpa a los diccionarios por la falta de un criterio lingüístico fiable a partir del cual se pueda estudiar el humor verbal. Es necesario, por lo tanto, intentar comprender qué mecanismos se ponen en funcionamiento en español para producir un enunciado humorístico y cómo reconocer este fenómeno verbal, tarea emprendida por el grupo GRIALE para después poder enseñarlo a los hablantes no nativos. 


\section{REFERENCIAS BIBLIOGRÁFICAS}

AHUMADA LARA, Ignacio (2004): «Exigencias al diccionario monolingüe de aprendizaje», en S. Ruhstaller y L. Berguillos, eds., La competencia lingüística y comunicativa en el aprendizaje del español como lengua extranjera, Madrid, Edinumen, pp. 83-96.

AtTARDO, Salvatore (1994): Linguistic Theories of Humour, Berlin, Mouton de Gruyter. (2001): Humorous Texts: A semantic and pragmatic analysis, Berlin, Mouton De Gruyter.

(2008): «Semantics and Pragmatics Humor», en Language and Linguistics Compass, vol. 2, Issue 6, pp. 1203-1215.

Ayala Manrique, Juan Francisco (1693): Tesoro de la Lengua Castellana, Madrid, Biblioteca Nacional de España, Ms. 1324.

AZORÍN FERNÁNDEZ, Dolores (2007): «La investigación sobre el uso del diccionario en el ámbito escolar», en Aparecida Negri Esquerdo e Ieda María Alves, eds., As Ciências do Léxico, Brasil, Editora UFMS \& Associação Editorial Humanitas, pp. 169-191.

(2010): «Las marcas de uso en los diccionarios monolingües de aprendizaje destinados a la enseñanza de ELE», en Agustín Vera Luján e Inmaculada Martínez, ed., El español en contextos especificos: enseñanza e investigación. Actas XX Congreso Internacional de ASELE, Comillas, Fundación Comillas, pp. 249-267.

y José Joaquín MARTíNEZ EGIDO (2010): «Sobre la utilidad de los diccionarios monolingües de aprendizaje (DMA) para estudiantes de ELE», en Stefan Ruhstaller y $\mathrm{M}^{\mathrm{a}}$ Dolores Gordón Peral, eds., Diccionario y aprendizaje del español, Bern, Peter Lang, pp. 89-132.

e Isabel SANTAMARÍA PÉREZ (2011): «La valoración», en Felix San Vicente, Cecilio Garriga y Hugo E. Lombardini, coords., Ideolex. Estudios de lexicografia e ideología, Monza, Polimetrica, pp. 203-221

BAtTANer Arias, Paz (2000): «Las palabras en el diccionario; el diccionario en el aula», en Actas del XI Congreso Internacional de ASELE, Zaragoza, Universidad de Zaragoza, pp. 61-90.

COVARrubias, Sebastián de (1611): Tesoro de la Lengua Castellana o Española, Madrid, Luis Sánchez.

DAcosta CEA, Vanessa (2004): «Las marcas de uso de los diccionarios de español con vistas al desarrollo pragmático de los alumnos de español L2», en Actas XV Congreso ASELE: Las Gramáticas y los Diccionarios en la Enseñanza del Es- 
pañol como Segunda Lengua: Deseo y Realidad, Sevilla, Universidad de Sevi1la, pp. 252-258.

Diccionario de la Lengua española, Madrid, Real Academia Española, 2001 (versiones papel y CDROM).

Diccionario para la enseñanza de la lengua española de la Universidad de Alcalá, Alcalá de Henares, VOX, 1995 [Alcalá].

ESCANDELL VIDAL, M M Victoria (2000): Introducción a la pragmática, Barcelona, Ariel.

- (2004): «Aportaciones de la pragmática», en Jesús Sánchez Lobato, e Isabel Santos Gargallo, dirs., Vademécum para la formación de profesores, Madrid, SGEL, pp. 179-197.

ETTINGER, Stefan (1998): «La variación lingüística en lexicografía», en Günther Haensch et al. (1998): La Lexicografía. De la lingüistica teórica a la lexicografía práctica, Madrid, Gredos, pp. 359-423.

FAJARDO AGUIRRE, Alejandro (1996-1997): «Las marcas lexicográficas: concepto y aplicación en la lexicografía española», Revista de Lexicografía, III, pp. 31-57.

GARRIGA ESCRIBANO, Cecilio (1999): «Diccionarios didácticos y marcas lexicográficas», en M. Neus Vila et al., eds., Así son los diccionarios, Lleida, Universitat de Lleida, pp. 43-75.

(1996): «La marca irónico en el DRAE: de Autoridades a 1992», en Esther Forgas, coord., Léxico y diccionarios, Tarragona, Universitat Rovira i Virgili, pp. 105-131.

(1998): Las marcas de uso en el Diccionario de la Academia: evolución y estado actual, Tarragona, Universitat Rovira i Virgili.

(1999): «El "registro familiar” como marca lexicográfica», en Pilar Díaz de Revenga y José Ma Jiménez Cano, eds., Estudios de Sociolingüística II. Sincronía y diacronía, Murcia, DM, pp. 95-106.

Grupo GRIALE (2011): ¿Estás de broma? 20 Actividades para practicar la ironía en clase de ELE, Madrid, Edinumen.

Guerra SAlas, Luis y Ma Elena Gómez SÁnChez (2005): «Pragmática y lexicografía: análisis de las marcas pragmáticas en el Diccionario Salamanca de la lengua española», en La competencia pragmática y la enseñanza del español como lengua extranjera, Actas del XVI Congreso Internacional de ASELE, Oviedo, 22-25 de septiembre de 2005, pp. 353-362. 
GuTIÉRREZ CUADRADO, Juan (1996): «Las marcas en los diccionarios para extranjeros», en Pilar Díaz de Revenga y José M Jiménez Cano, eds., Estudios de Sociolingüística II. Sincronía y diacronía, Murcia, DM, pp. 95-106.

Universidad de Salamanca-Santillana.

GUTIÉRREZ ORDOÑEZ, Salvador (2004): «La subcompetencia pragmática», en Jesús Sánchez Lobato e Isabel Santos Gargallo, dir., Vademécum para la formación de profesores, Madrid, SGEL, pp. 533-552.

HERNÁNDEZ, Humberto (1993): «De la teoría lexicográfica al uso del diccionario: el diccionario en el aula», en Salvador Montesa Peydró y Antonio Garrido Moraga, eds., El español como lengua extranjera: de la teoría al aula. Actas del III Congreso Nacional de ASELE, Málaga, Universidad de Málaga, pp.189-199.

(1998): «La lexicografía didáctica del español: aspectos históricos y críticos», en M. T. Fuentes Morán y R. Werner, Lexicografías iberorrománicas: problemas, propuestas y proyectos, Frankfurt, Vervuert, pp. 49-79.

Hidalgo Downing, Raquel y Silvia IgLesias Recuero (2009): «Humor e ironía: una relación compleja», en L. Ruiz Gurillo y X. Padilla García, eds., Dime cómo ironizas y te diré quién eres. Una aproximación pragmática a la ironía, Frankfurt, Peter Lang, pp. 423-456.

IGLESIAS CASAL, Isabel (2000): «Sobre la anatomía de lo cómico: recursos lingüísticos y extralingüísticos del humor verbal», en María Antonia Martín Zorraquino y Cristina Diez Pelegrín, eds., ¿Qué español enseñar? Norma y variación lingüística en la enseñanza de español como lengua extranjera. Actas del XI Congreso Internacional de ASELE, Zaragoza, Universidad de Zaragoza y Centro Virtual Cervantes, pp. 439-449.

JimÉnez HuRTAdo, Catalina (2001): Léxico y Pragmática, Frankfurt, Peter Lang.

LeVInson, S. C. (2000): Presumptive meanings, Cambridge (Mass.), MIT Press.

Marco común europeo de referencia para las lenguas: aprendizaje, enseñanza, evaluación [cvc.cervantes.es/ensenanza/biblioteca_ele/marco/].

MARIMÓN LlORCA, Carmen (2004-2005): «Sobre el sentido irónico en español. Aspectos pragmáticos y lexicográficos», EPOS, XX-XXI (2004-2005), pp. 33-54.

MARSÁ, Vicente, dir. (2002): Diccionario de la Lengua Española para Estudiantes de Español, Madrid, Espasa Calpe. 
PÉREZ LagOS, Femando (1999): «Diccionario y pragmática», en M. Alvar Ezquerra y G. Corpas Pastor, coords., Léxico y voces del español, Málaga, Universidad de Málaga, pp. 113-126.

PONS, Salvador (2005): La enseñanza de la pragmática en la clase de E/LE, Madrid, Arco/Libros.

RASKIN, Victor (1985): Semantics Mechanismof humor, Dordrecht, D. Reidle Publishing.

REYES, Graciela (1990): La pragmática lingüística, Barcelona, Montesinos. (2002): Metapragmática. Lenguaje sobre lenguaje, ficciones, figuras, Valladolid, Universidad de Valladolid.

RocA, Santiago (2009): «Ironía e interculturalidad», en L. Ruiz Gurillo y X. Padilla García, eds., Dime cómo ironizas y te diré quién eres. Una aproximación pragmática a la ironia. Frankfurt, Peter Lang, pp. 457-477.

RUIZ GuRILlo, Leonor (2006): Hechos pragmáticos del español. Alicante, Universidad de Alicante. (2009): «La gramaticalización de unidades fraseológicas irónicas», en L. Ruiz Gurillo y X. Padilla García, eds., Dime cómo ironizas y te diré quién eres. Una aproximación pragmática a la ironía, Frankfurt, Peter Lang, pp. 371-390.

y X. PADIlla García, eds. (2009): Dime cómo ironizas y te diré quién eres. Una aproximación pragmática a la ironía, Frankfurt, Peter Lang.

SANTAMARÍA PÉREZ, Isabel (2004): «La información gramatical en los diccionarios monolingües de aprendizaje: reflexiones a partir del verbo», en J. L. Cifuentes Honrubia y C. Marimón, eds., Estudios de lingüística: el verbo, Alicante, Universidad de Alicante, pp. 559-580.

(2009): «Los evidenciales», en L. Ruiz Gurillo y X. Padilla García, eds., Dime cómo ironizas y te diré quién eres. Una aproximación pragmática a la ironía. Frankfurt, Peter Lang, pp. 267-292.

(2010): «Pragmática y lexicografía: análisis del sentido 'humorístico' en los diccionarios didácticos del español», en IV Congreso de Lexicografía Hispánica, Tarragona, Universitat Rovira i Virgili (en prensa).

TORRES SÁNCHEZ, M. Ángeles (1999): Estudio pragmático del humor verbal, Cádiz, Universidad de Cádiz. 
Traugot, E. C. y R. B. DASHer (2002): Regularity in Semantic Change, Cambridge, Cambridge University Press.

VEALE, Tony (1991): «Incongruity in Humor: Root Cause or Epiphenomenon?», en The International Journal of Humor Research, 4 (3-4), pp. 293-347. 